\title{
A New Sequence Stratigraphic Framework of Terrestrial Fluvial
}

\author{
Zhipeng Lin ${ }^{1,2}$, Le Chen ${ }^{1,2}$, Jingfu Shan ${ }^{1,2}$, Tan Zhang ${ }^{1,2}$, Qianjun Sun ${ }^{3}$, Yiwu Wang ${ }^{4}$ \\ ${ }^{1}$ Key Laboratory of Exploration Technologies for Oil and Gas Resources, Ministry of Education, Yangtze University, \\ Wuhan, China \\ ${ }^{2}$ School of Geosciences, Yangtze University, Wuhan, China \\ ${ }^{3}$ School of Energy Resources, China University of Geosciences, Beijing, China \\ ${ }^{4}$ School of Earth and Space Sciences, Peking University, Beijing 100871, China \\ Correspondence: Zhipeng Lin, Key Laboratory of Exploration Technologies for Oil and Gas Resources, Ministry of \\ Education, Yangtze University, Wuhan, China. E-mail: lzp19920626@gmail.com
}

Received: July 2, 2016 Accepted: July 27, 2017 Online Published: July 31, 2017

doi:10.11114/set.v4i1.2521

URL: https://doi.org/10.11114/set.v4i1.2521

\begin{abstract}
Currently, the recognition and research on the classification of fluvial types mainly focus on the description and results of a series of indicators, such as the plane shape and sediment characteristics. However, there is limited literacy about how to demonstrate the fluvial types from the depositional process, especially less on sequence model of inland fluvial. Thus, this paper aims o propose a new kind of sequence stratigraphic framework, which is able to reflect the fluvial processes under the perspective of sequence stratigraphy. Accordingly, we use the principle of concrete analysis for concrete problems by comprehensively summing up the previous classification schemes of river types. With the research method of sedimentation process, new fluvial systems tracts for fluvial are presented here, including four parts: low fluvial system tract (LFST), advancing fluvial system tract (AFST), flooding fluvial system tract (FFST), receding fluvial system tract (RFST). Moreover, these could be applied to tackle the problem of the traditional division of fluvial. Various rivers have the different characteristics of systems tracts, then this may play a vital role in the discrimination of meandering river, braided river, anastomosing river and branched river. This study embodies the philosophical thought of Process Sedimentology and may contribute to revealing the deposition process of the fluvial system more profoundly from the aspect of genetic mechanism and evolution course. Most importantly, the fluvial classification system is definitely improved from the description stage to a complete rational stage.
\end{abstract}

Keywords: sequence stratigraphic framework, fluvial, sedimentation process, fluvial systems tracts

\section{Introduction}

With the continuous deepening study on the fluvial sedimentary system, the emergence of new fluvial encourages increasing numbers of scholars to recognize the gradually prominent contradictions between the fluvial types and the traditional classification scheme. For instance, Leopold and Wolman (1957) had put forward the classification of the meandering river and braided river very early. But in the actual situation, braided river and meandering river do not exist independently in a geological period, they will coexist in a same provenance system during a special condition, and will also make reciprocal transformation with the development of the geological evolution (Tan et al., 2014; $\mathrm{Wu}$, Lin, Liu, \& Qian, 2014; Tang et al., 2016; Kasvi, Laamanen, Lotsari, \& Alho, 2017; Lin, Shan, \& Chen, 2017a). Miall (2014) classified fluvial as four types: braided river, meandering river, anastomosing river and straight river. However, Qian Ning, afterwards, referred that this scheme of anastomosing river was inappropriate to be taken into the anabranching rivers (Stout, Rutherfurd, Grove, \& Kemp, 2016; Leli, Stevaux, \& Assine, 2017; Morón, Edmonds, \& Amos, 2017) in the mid-lower Yangtze River and the wandering river in the lower reaches of the Yellow River. This view has been accepted gradually around foreign countries (Qian, 1985; Zhang, Zhang, Li, Dan, \& Hou, 2004; Wu, Hou, Wang, Cui, \& Shuqing., 2014; Lin, Chen, Shan, Sun, \& Wang, 2017). The understanding of fluvial type still stays in the view of the appearance and the results. Therefore, there is a pressing need for a new way of a train of thought and research methods (Chen, Lin, Yin, Sun, \& Wang, 2017; Lin, Chen, Shan, \& Sun, 2017; Shan et al., 2017).

Nevertheless, numerous scholars pay more attention on the perspective of fluvial sediment results, rather than from the cause of the genetic process. Eventually, lead to the randomness and chaos of river classification system, resulting in the 
discount of credibility and operability greatly. If the deposition process can be recovered from the perspective of sedimentation process, then the outcoming river types could be more credible and practical. While the best indicator of the sedimentation process is the fluvial sequence. The sequence stratigraphic framework of river system has been done some research by some predecessors. In 1988, the first non-marine alluvial sequence stratigraphy models were established (Posamentier, Jervey, \& Vail, 1988; Posamentier \& Vail, 1988).

Based on the results, Wright and Marriott (1993) systematically proposed a simple sequence model for the fluvial facies. Then argued that the lowstand systems tract (LST) was composed of channel fillings in incised valley and terrace soil layer, the transgressive systems tract (TST) featured with the uplifting of base level and the growth of accommodation space, the highstand systems tract (HST) has an increasing channel sand body density and more soil layer.

Subsequently, in the summary of the control action for accommodation space from the tectonic subsidence, material supply, and many other factors, Shanley and McCabe (1994) proposed a set of fluvial facies strata sequence pattern from the mode of deposit loading. On the basis of summarizing the previous models of the predecessors, Zhang Zhouliang (1996) explained his sequence model by comparing the differences of similarities, advantages, and disadvantages of previous patterns, systematically. And for the first time, he pointed out the relationship between the stratigraphic sequence with fluvial types. It is pointed out that the LST is favorable for the formation of the braided river, the TST is favorable for the formation of the anabranching rivers, and the HST is favorable for the formation of a meandering river. The model is also described in terms of the sequence of the fluvial stratigraphic strata and the river type in the Permian Shanxi Formation in the northern section of Helan Mountain.

Table 1. Classification scheme of fluvial types

\begin{tabular}{|c|c|c|c|c|}
\hline Scholar & Time[year] & $\begin{array}{l}\text { Classification } \\
\text { basis }\end{array}$ & Classification index & Fluvial types \\
\hline $\begin{array}{l}\text { Powell } \\
\text { \&Davis }\end{array}$ & 1875 & structure control & structural control factor & $\begin{array}{l}\text { along the river, reverse river, antecedent river, } \\
\text { subsequent river, superimposed River }\end{array}$ \\
\hline Davis & 1899 & erosion cycle & different erosion stage & childhood, prime, old age \\
\hline $\begin{array}{l}\text { Leopold } \\
\& \text { Wolman }\end{array}$ & 1957 & channel pattern & channel pattern & straight river, meandering river, braided river \\
\hline Schumm & 1963 & $\begin{array}{l}\text { sediment } \\
\text { transport }\end{array}$ & sediment transport & lapse river, suspended river, mixed river \\
\hline Drury & 1969 & channel pattern & channel pattern & $\begin{array}{l}\text { braided river, meandering river, anastomosing } \\
\text { river, straight river, anabranched river }\end{array}$ \\
\hline Miall & 1977 & channel pattern & channel pattern & $\begin{array}{l}\text { braided river, meandering river, anastomosing } \\
\text { river, straight river }\end{array}$ \\
\hline Galloway & 1978 & $\begin{array}{l}\text { sediment } \\
\text { transport }\end{array}$ & sediment transport & lapse river, suspended river, mixed river \\
\hline Rust & 1978 & channel pattern & $\begin{array}{l}\text { channel anabranched index } \\
\text { and bending }\end{array}$ & $\begin{array}{l}\text { braided river, meandering river, anastomosing } \\
\text { river, straight river }\end{array}$ \\
\hline Brice & 1983 & channel pattern & channel pattern & $\begin{array}{l}\text { curved channel, curved beach type, micro } \\
\text { bending braided, straight braided type }\end{array}$ \\
\hline Qianning & 1985 & channel pattern & channel pattern & $\begin{array}{l}\text { wondering river, meandering river, straight } \\
\text { river, anabranched river }\end{array}$ \\
\hline Woolfe & 1996 & $\begin{array}{l}\text { sedimentation } \\
\text { rate }\end{array}$ & sedimentation rate & mountain rivers, plain rivers, delta river, etc. \\
\hline Wang Shuiji & 1999 & channel pattern & $\begin{array}{l}\text { bending degree and channel } \\
\text { system }\end{array}$ & $\begin{array}{l}\text { braided river, meandering river, anastomosing } \\
\text { river, straight river, anabranched river }\end{array}$ \\
\hline Xu Caicai & 2015 & \multicolumn{2}{|c|}{$\begin{array}{l}\text { river level, the degree of closure, the number of } \\
\text { river and winding degree }\end{array}$} & 20 types of rivers \\
\hline
\end{tabular}


deposition of the river system. What now mostly proposed is the coastal fluvial sequence stratigraphic model, but there are many problems that are not suitable for the inland fluvial system (Huang, $\mathrm{Wu}, \mathrm{Li}, \& \mathrm{Liu}, 2016$ ). In order to solve these problems, the paper tries to combine the formation process of the fluvial sequence and the channel evolution, and then reconstructs a set of sequence stratigraphic framework for the river, moreover, makes it respond to the fluvial type.

\section{Theoretical Basis}

Rivers are usually divided into the braided river, meandering river, anabranching river and straight river four types. The main basis for this division is the degree of curvature, bifurcation coefficient and stability. Braided rivers and meandering rivers are the most highly studied rivers. The braided river has relatively low curvature and multi-channel system, the slope is larger with coarse grain bed load, is a kind of high-energy fluvial. The stability of this river is relatively poor, usually in the lateral direction can have a greater distance migration and swing, which ultimately form a wide range of sheets sand body. By way of contrast, the meandering river is a kind of single river system with a relatively high curvature. The slope of the river basin is generally small, usually with mixed or suspension load. Sedimentation is mainly due to the lateral filling effect and the vertical accumulation of the river bank and the shore. In recent years, the study of anabranching rivers has been paid increasingly important attention. It is a low-slope, low-energy and multi-channel river composed of frequently bifurcated and confluent phenomena, thus forming an intertwined river network system. On both sides of the river, there are very developed natural dikes and fine particles composed of spill deposition, often with high lateral stability. In the stratigraphic record, the deposition of the anabranching river is an absolute advantage in the sedimentation of the spillway. The channel sand bodies are usually narrower in the band and both sides are limited by natural levees. The straight rivers are relatively rare, characterized by lower curvature, generally shorter, and shorter in geological history. Their sedimentary characteristics are similar to the meandering river, and the lateral filling of the sand bars on both sides of the river can change the location of the river.

With the rise and rapid development of sequence stratigraphy, especially in the study of continental sequence, it has become increasingly clear that fluvial deposits in basins are not only developed autogenic controls (such as river diversion), but also by some external factors (such as climate, structure, etc.), and the development of some of his records of the allogenic cycle. These external factors affect the scope larger sometimes. Because of their rotation in the stratigraphic record should also have regional comparability, the sequence stratigraphy of the fluvial facies established on the basis of these regimes provides a way to solve the problem of river-bed stratigraphy, which is usually very difficult.

\subsection{Current Fluvial Classification Division Scheme}

River classification is the basis of the establishment of facies model and is also the term used in the petroleum geology work. In the continental petroleum basin, fluvial sandbody is very important, and it has attracted people's attention for many years. Table 1 lists a brief introduction to the classification status of fluvial classification division scheme, for reference only.

Table 2. The development stages of sequence stratigraphy

\begin{tabular}{|c|c|c|c|}
\hline Scholar & Time[year] & Content stage & Stage \\
\hline Sloss & 1950 & The concept of sequence is put forward & \\
\hline Vail & 1977 & Founded seismic stratigraphy & Origin stage \\
\hline Vail & 1987 & $\begin{array}{l}\text { Used stratigraphic unconformity or unconformity with the integrated interface } \\
\text { as the sequence boundary; Took the seismic data to interpret the seismic } \\
\text { stratigraphy. And then based on the relationship between the sequence and } \\
\text { sequence unconformity interface, explained the sedimentary system and } \\
\text { depositional system, In particular, the global sea level change was the main } \\
\text { control factors of sequence development }\end{array}$ & Classical \\
\hline Galloway & 1989 & $\begin{array}{l}\text { Used the maximum flooding surface and its corresponding sedimentary } \\
\text { section as the sequence boundary, and the data of the well were used to } \\
\text { analyze the sedimentary system. In particular, the sequence is a set of } \\
\text { sediments deposited along the edge of the basin. }\end{array}$ & $\begin{array}{l}\text { sequence } \\
\text { stratigraphy } \\
\text { stage }\end{array}$ \\
\hline Johnson & 1992 & $\begin{array}{l}\text { Used the stratigraphic unconformity or transgressive erosion unconformity } \\
\text { interface as transgressive-regressive cycle, that is, from a enhance mutual } \\
\text { events to another with equal in size to the deepening of events prior to the } \\
\text { start of a period of time in the deposited layers }\end{array}$ & \\
\hline Cross & 1995 & $\begin{array}{l}\text { High-resolution sequence stratigraphy theory was proposed, which includes } \\
\text { the principle of the reference plane, the principle of volume partition, the } \\
\text { principle of phase differentiation and the comparison of the cycles. }\end{array}$ & $\begin{array}{l}\text { high-resolution } \\
\text { sequence } \\
\text { stratigraphy }\end{array}$ \\
\hline
\end{tabular}

Gurnell et al. (Gurnell, Angold, \& Gregory, 1994) believed that classification was a cognitive process of complex things, according to the principle of cognition, there are three ways of classification. Leopold and Wolman (Leopold \& Wolman, 
1960) proposed the classification of " straight river, meandering river, and braided river" according to the channel pattern. In accordance with the geometric characteristics, Rosgen (Rosgen, 1994) proposed geomorphic classification framework. Montgomery et al. (Montgomery \& Buffington, 1997) and Croke are in line with the method of prototype theory to some extent.

\subsection{The Development and Application of the Theory of Sequence Stratigraphy.}

Although the theory of sequence stratigraphy is proposed based on the continental strata in the context of passive continental margins, more and more geotechnical workers have tried to apply the concepts and theories of sequence stratigraphy to the fluvial stratigraphy. The sequence stratigraphy is a comprehensive interpretation science for stratigraphic sequence framework. It is integrated with seismic stratigraphy and the comprehensive utilization of seismic, drilling and outcrop data, combined with the sedimentary environment as well as lithofacies and ancient geographical interpretation. In the concept of geological history, it is based on biostratigraphy and chronostratigraphy established by the macro-age stratigraphic framework based on the study. In theory and method, it will become an integrant part of geology and geophysics, and gradually formed a relatively independent theoretical method system (Yang, 2009; Shan, Wang, Sun, Sun, \& Meng, 2010; Crombez, Rohais, Baudin, \& Euzen, 2016).

The development phases of sequence stratigraphy can be divided into three stages: the origin stage, the classical sequence stratigraphy stage and the high-resolution sequence stratigraphy (Xiao, Liu, \& Chen, 2006). The three stages are visible in Table 2. It can be seen, as one of the forefronts of the earth science research, the theory and practice of sequence stratigraphy has brought a leap to the theory and mind, and therefore it has won much of the popular (Sloss, 1963; Vail, Mitchum Jr, \& Thompson III, 1977; Vail, 1987; Galloway, 1989; Johnson \& Klapper, 1992).

In the meantime, it can also be seen that the development of sequence stratigraphy is still mainly focused on the control factors of sea and base level, and the severe challenge in the application of continental oil and gas basins are outstanding mainly due to the theory of classical sequence stratigraphy is developed counting on the passive continental margin. Though its sea level migration characteristics are relatively recognizable. However, this feature is not applicable to the inland basins, especially for the terrestrial rivers. The traditional stratigraphic system is divided into low water systems tract (LST), transgressive systems tract (TST), and highstand systems tract (HST). But this kind of system can not ideally correspond with the inland fluvial process. Therefore, for the identification and division of terrestrial river sequences, further study is indeed essential.

\section{Terrestrial River Sequences Framework}

\subsection{River Sequence Stratigraphic Model}

There exist two problems, one is the classification of the traditional river, the other is the traditional sequence stratigraphy issues. Initially, attempts were made to explain the relationship between the formation of river facies deposited on the plains of the sea and sea level changes. Since these fluvial strata are interbedded with the marine strata, their relationship with the sea level as a base is easier to understand. Posameniter and Vail (1988) argued that there are two types of fluvial facies associated with type I: one is the fluvial filling deposites in the incised valley during the global sea level decline, showing a linear and curved distribution model; another formed in the later stage of high water level in the plains, widely distributed in the lateral unrestricted. The type II sequence only forms a widely distributed river facies deposit at a later stage in the high water, without the cutoff fillings. The river sequence stratigraphic patterns of different scholars are shown in Table 3. For now, at home and abroad on the river classification is still a public statement, no agreement, the main reason is that there is no recognized a unified standard, and even the understanding of the river is not consistent. 
Table 3. River sequence patterns of different scholars

\begin{tabular}{|c|c|c|c|c|}
\hline Scholar & Year & Systems tract & Features & Fluvial types \\
\hline \multirow[t]{2}{*}{$\begin{array}{l}\text { Posamentier } \\
\text { \&Vail }\end{array}$} & \multirow[t]{2}{*}{1888} & I type sequence & $\begin{array}{l}\text { Sea level falls incised valley fillings, linear and curved } \\
\text { distribution. } \\
\text { The Late stage of high water level, widely distributed in the } \\
\text { plain, in the lateral is not restricted. }\end{array}$ & \\
\hline & & $\begin{array}{l}\text { II } \quad \text { type } \\
\text { sequence }\end{array}$ & $\begin{array}{l}\text { In the late stage of high water level, river facies are widely } \\
\text { deposited, and there is no filling in the valley. }\end{array}$ & \\
\hline \multirow{3}{*}{ wright } & \multirow{3}{*}{1993} & $\begin{array}{l}\text { Lowstand } \\
\text { systems tract }\end{array}$ & $\begin{array}{l}\text { Composed of the incised valley fillings and the high maturity of } \\
\text { soil layer, topographic slope larger, in the source region of the } \\
\text { denudation rate is higher. }\end{array}$ & $\begin{array}{l}\text { low sinuosity } \\
\text { river }\end{array}$ \\
\hline & & $\begin{array}{l}\text { Transgressive } \\
\text { systems tract }\end{array}$ & $\begin{array}{l}\text { Uplift of the base surface, increasing the accommodation } \\
\text { space. The vertical accretion rate increases, and the distribution } \\
\text { of a wide range of thick layers of the floodplain deposition. }\end{array}$ & $\begin{array}{l}\text { Isolated and } \\
\text { laterally } \\
\text { confined river }\end{array}$ \\
\hline & & $\begin{array}{l}\text { Highstand } \\
\text { systems tract }\end{array}$ & $\begin{array}{l}\text { Accommodation space growth rate decreased, The increase rate } \\
\text { of the river floodplain is reduced, The density of river sand body } \\
\text { increases. }\end{array}$ & - \\
\hline \multirow{3}{*}{$\begin{array}{l}\text { Shanley } \\
\text { McCabe }\end{array}$} & \multirow{3}{*}{1994} & $\begin{array}{l}\text { Lowstand } \\
\text { systems tract }\end{array}$ & $\begin{array}{l}\text { The channel sand bodies are horizontal and vertical to each } \\
\text { other, and the bed load is mainly coarse grain, and Upward } \\
\text { coarsening. }\end{array}$ & braided river \\
\hline & & $\begin{array}{l}\text { Transgressive } \\
\text { systems tract }\end{array}$ & $\begin{array}{l}\text { The bed load and suspended load are mixed, and the bed load } \\
\text { can be changed to a fine and can accommodate space growth. }\end{array}$ & $\begin{array}{l}\text { meandering } \\
\text { river, }\end{array}$ \\
\hline & & $\begin{array}{l}\text { Highstand } \\
\text { systems tract }\end{array}$ & $\begin{array}{l}\text { The suspended load is the main form of the channel sand body } \\
\text { and more soil layer, which can slow down the speed of space } \\
\text { growth. }\end{array}$ & $\begin{array}{l}\text { anastomosing } \\
\text { river }\end{array}$ \\
\hline \multirow{3}{*}{$\begin{array}{l}\text { Zhang } \\
\text { Zhouliang }\end{array}$} & \multirow{3}{*}{1996} & $\begin{array}{l}\text { Lowstand } \\
\text { systems tract }\end{array}$ & $\begin{array}{l}\text { The gravel sediment filling, river vertical cutting each other, } \\
\text { mutually overlapping, contiguous transverse distribution of sand } \\
\text { body. }\end{array}$ & braided river, \\
\hline & & $\begin{array}{l}\text { Transgressive } \\
\text { systems tract }\end{array}$ & $\begin{array}{l}\text { Fine sediment deposition, which contains some of the narrow } \\
\text { band channel sand body. }\end{array}$ & $\begin{array}{l}\text { anastomosing } \\
\text { river }\end{array}$ \\
\hline & & $\begin{array}{l}\text { Highstand } \\
\text { systems tract }\end{array}$ & $\begin{array}{l}\text { The uplift rate of the surface is slow, accommodation space } \\
\text { growth rate is lower. }\end{array}$ & $\begin{array}{l}\text { meandering } \\
\text { river, }\end{array}$ \\
\hline \multirow{4}{*}{ Fangshi } & \multirow{4}{*}{1997,2000} & $\begin{array}{l}\text { Lowstand } \\
\text { systems tract }\end{array}$ & $\begin{array}{l}\text { The sand body in the horizontal, vertical contiguous, associated } \\
\text { with the previous soil on the terrace. }\end{array}$ & braided river, \\
\hline & & $\begin{array}{l}\text { Transgressive } \\
\text { systems tract }\end{array}$ & $\begin{array}{l}\text { Two stage, first is the water surface increased, the large area of } \\
\text { the development of the marsh, the formation of peat and coal } \\
\text { bed, often to the bottom of the coal bed or mud layer. Then, the } \\
\text { base surface uplift rate increases, the formation of a set of fine } \\
\text { grain vertical to the accumulation of the characteristics of the } \\
\text { deposit, associated with better preservation of coal }\end{array}$ & $\begin{array}{l}\text { meandering } \\
\text { river, } \\
\text { anastomosing } \\
\text { river }\end{array}$ \\
\hline & & $\begin{array}{l}\text { Highstand } \\
\text { systems tract }\end{array}$ & $\begin{array}{l}\text { The base surface of the largest uplift, the rate of change is } \\
\text { reduced, coal, peat, soil, etc. }\end{array}$ & $\begin{array}{l}\text { meandering } \\
\text { river, }\end{array}$ \\
\hline & & $\begin{array}{l}\text { Regressive } \\
\text { systems tract }\end{array}$ & $\begin{array}{l}\text { The base surface uplift rate decreases, erosion of some of the } \\
\text { material deposited in the high water level. }\end{array}$ & braided river, \\
\hline
\end{tabular}

\subsection{New Ideas for the Division of the River Sequence Framework}

The river is a very important source transport system that transfers sediments from provenance areas to sedimentary basins and oceans. In the newly proposed source-sink system (Archer, 2017; Bonneau et al., 2017; Hawie et al., 2017; Mason et al., 2017)-the source formed from the eroded area, including the weathered particles of sediment and dissolved matter, is transported to the sedimentary area or sink basin in the final deposition. The river can definitely be regarded as its "blood". It is not only an important channel for the flow of land from the inland to the lake and the oceans (Miall, 2016; Lin, 2017; Lin, Shan, \& Chen, 2017b), but also an important medium for the completion of the entire ecological cycle. Therefore, the full and complete understanding of the river is of vital importance to the whole geology study. At present, the understanding and division of the river system still mainly focus on the results, and lack of analysis of formation process. This paper presents the process of sedimentology, that is, from the perspective of the formation process to explore the sediments from the transport to the final deposition process of geological phenomena and records. Through the study of these process records, reconstruction of the entire deposition process may be completed. Applied to the river sedimentary system, is to analyze and understand the geological record of the river sedimentation process - the river sequence stratigraphic framework. 


\subsubsection{Influence Factors of the River Sequence}

In 2000, it was concluded that the interaction between the supply and the accommodation space of the sediment is an important factor to affect the sequence of the river. In sequence stratigraphy, 4 control factors, such as tectonic subsidence, global sea level fluctuation, sediment supply and climate change, are the basic factors. However, the river basin has its own characteristics and its influencing factors are unique, which can not be decided in general terms on the existing sequence systems.

The discussion of the main factors of the river is the establishment of the river sequence model, which must be involved in the core issues. In the earlier stage, the classical sequence stratigraphy theory originated from the passive continental margin was used to link the sea level change and the river sediment structure. The researches of Shanley et al. (1994), Wright et al. (1993) and van Wagoner (1995) all linked the river sedimentary characteristics with the sea level change.

The classical sequence stratigraphy summarizes the four elements: tectonic subsidence, global sea level change, sediment supply, and climate change. But in fact, these elements are reflected in the base changes, which are the result of these elements of the integrated results, and changes in the base control the characteristics of sequence development. But the impact of sea level changes on the river is limited, Catuneanu (2006) thought that the influence of sea level change and shoreline migration on the river sequence is generally only tens of kilometers from the shoreline to the upper reaches of the river. For example, sea level changes affect the Colorado River by about $90 \mathrm{~km}$, to the low-lying Java continental shelf of the Pleistocene, the impact of the maximum is more than $200 \mathrm{~km}$. Therefore, it is not appropriate to apply Shanley, Wright and van Wagoner models to inland rivers away from the ocean.

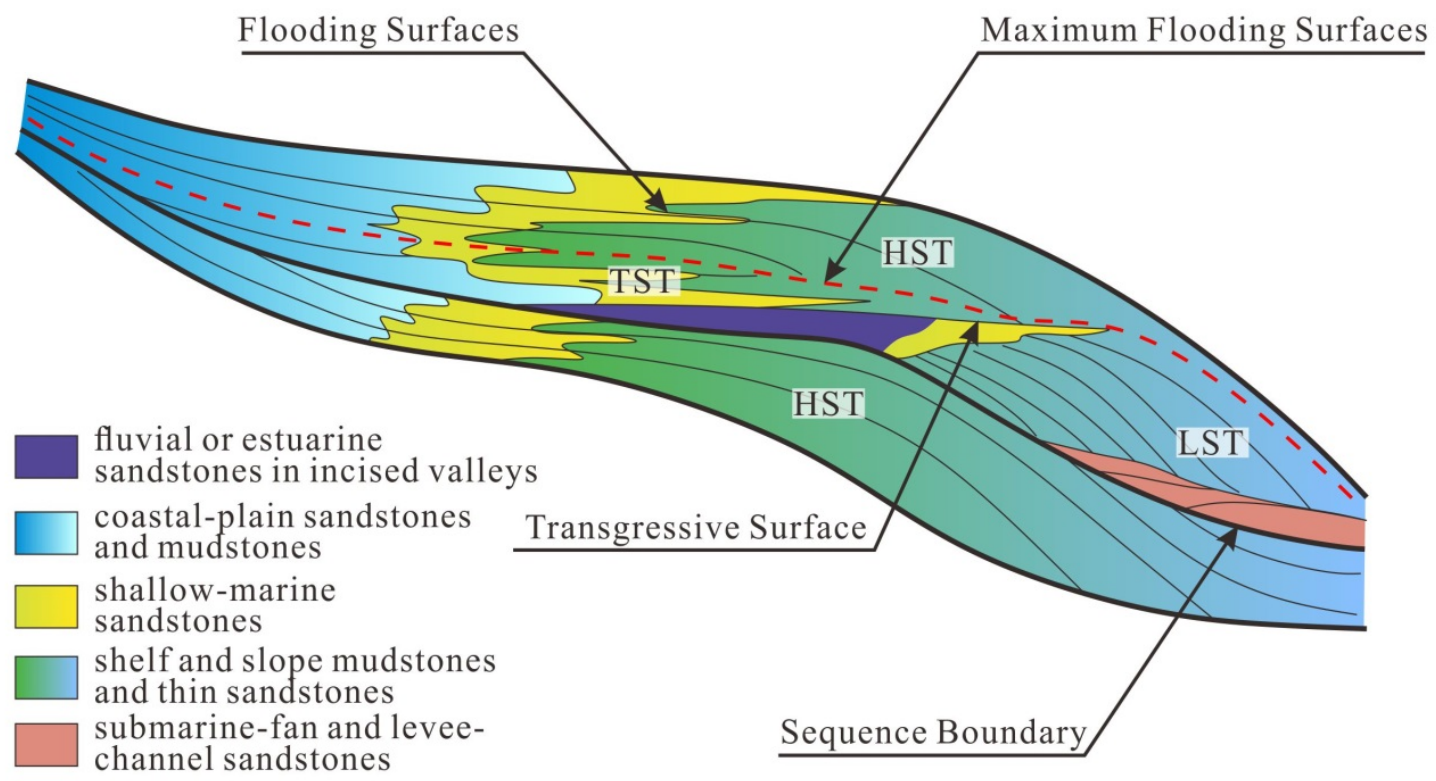

Figure 1. Type-I-Sequence modified from Van Wagoner

For inland rivers, in addition to the tectonic and climatic factors, the riparian and floodplain material composition, vegetation coverage, basin sediment size, and sediment composition, flow rate changes can affect the base surface changes in a certain extent, thus influence river sediment (Sanz-Perez \& Menendez-Pidal, 2016; Debnath, Pan, Ahmed, \& Bhowmik, 2017; Fryirs, 2017; Hawie et al., 2017).

The change of the base is a function of the influencing factors, and the influence of each factor on the change of the base is studied on a case-by-case basis. Theoretically, it is the most accurate way for reflection of the change feature of the base plane, but the base is a dynamic abstract surface, the difference in the contribution rate of each factor to the base change is different at different times. Thus this complexity means that it is not realistic to consider all the factors to study the change of the base. And the various influencing factors are related, such as the effect of sediment supply to the source area and the influence of climate, the regulation of the river is also controlled by the structure, and the change of the flow rate is controlled by the climate. Therefore, fundamentally, the structure and climate are the main controlling factors in the inland rivers baseline changes, which is consistent with the idea that Catuneanu believes that the upper reaches of the river's range of changes beyond the sea level are mainly controlled by tectonics and climate. Therefore, it is more practical to grasp the two factors of structure and climate to study the change of the reference plane than to consider all the influencing factors. 


\subsubsection{Sequence Boundary of Fluvial}

In stratigraphic records, two types of sequences can be identified, that is, the type I and type II (Van Wagoner, 1995). Respectively correspond to the type I boundary and type II boundary. Type I boundary refers to a regional unconformity that occurs when the global sea level descending velocity is greater than the sedimentation velocity at the basin slope at the depositional slope (Fig. 1). And the sea level is relatively reduced, which is characterized by the migration of the sedimentary basin, the migration of the superstructures on the coast and the continental erosion associated with the overlying strata. The type II boundary is due to the fact that the global sea-level descending velocity is less than the sedimentation rate at the basin slope (Fig. 2), where the relative decline in sea level does not occur. It has the characteristics of land expansions, overlying strata and ultra-downward migration on the coast. However, it does not accompany with the erosion of the land and the migration of the sedimentary facies to the basin.

However, the boundary of the river, no one yet puts forward. In this paper, the river should have a unique sequence boundary, whether it is a meandering river, braided river or anabranching river, the inland river system sequence boundary is related to its influencing factors.

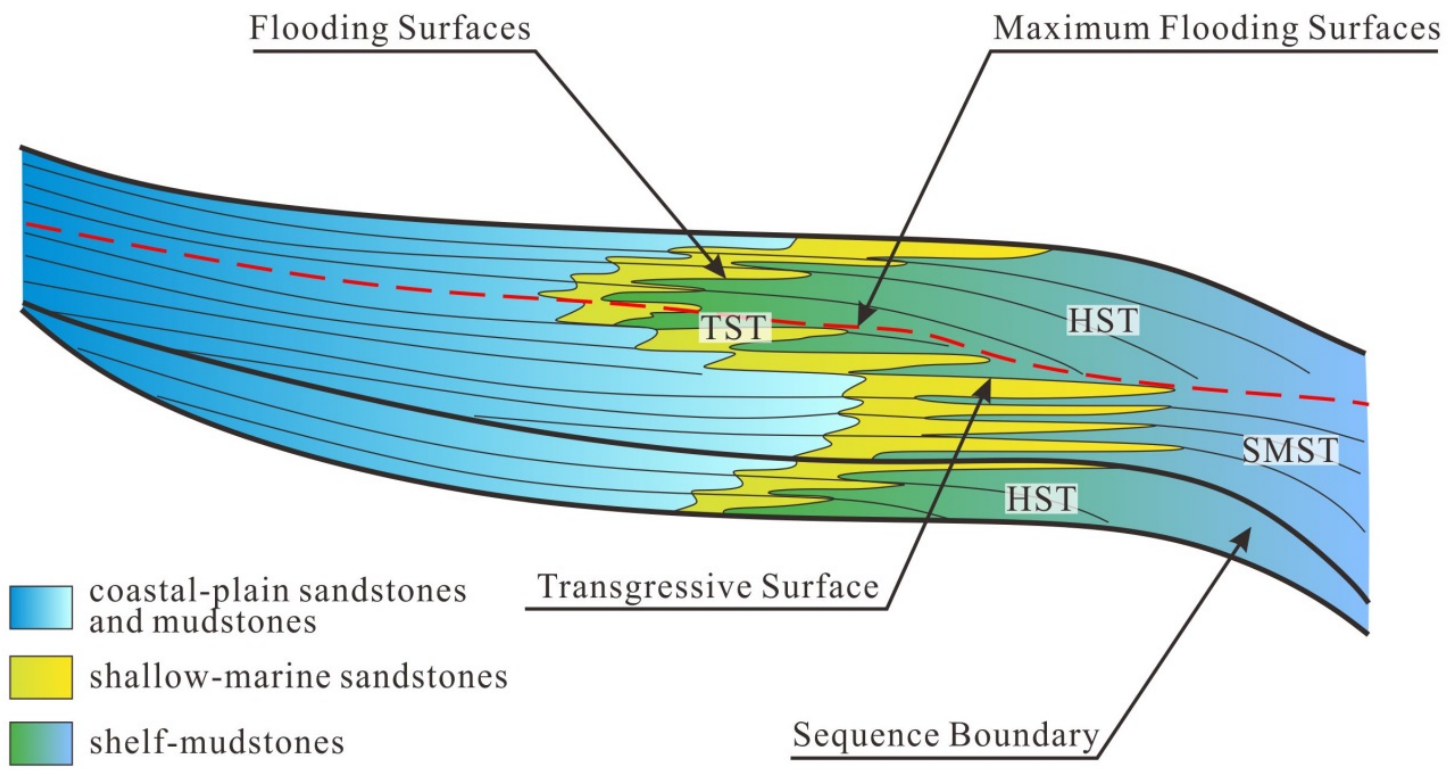

Figure 2. Type-II-Sequence modified from Van Wagoner.

\subsection{Sequence Stratigraphic Model of Fluvial Facies in Fluvial System}

The existing river sequence stratigraphic model, intended to reconstruct the sequence stratigraphic model for river systems. Hu Guangming (Hu, Ni, Wang, \& Zhao, 2011) argues that the formation of inland rivers generally caused by the decline in the base caused by the river down the formation of rivers and terraces (referred to as the valley stage), the base rise caused by the valley was filled or even covered (referred to as the valley stage) two stages. In the fluvial facies stratigraphic model proposed by Shanley et al., Wright et al., Zhang et al., Zhang Wulong, and Liu Zhaoyun et al., the river sequences that are embodied in the valley are actually benchmarked and increased (relative to the rise of the bed). Since the thickness of the sediment is increasing from the bottom of the lower cut valley, indicating that the benchmark has been rising, but the speed of the rise is different, which led to the variety of the degree of sand body cutting, sand and mud ratios, and the river types. And since can be figured out from the Figure 3, different levels of the benchmark and the cycle, theoretically are formed by the rise and decline of the semi-cycle. Therefore, the sequence stratigraphic model is not complete and not suitable for river sequence stratigraphic framework. 


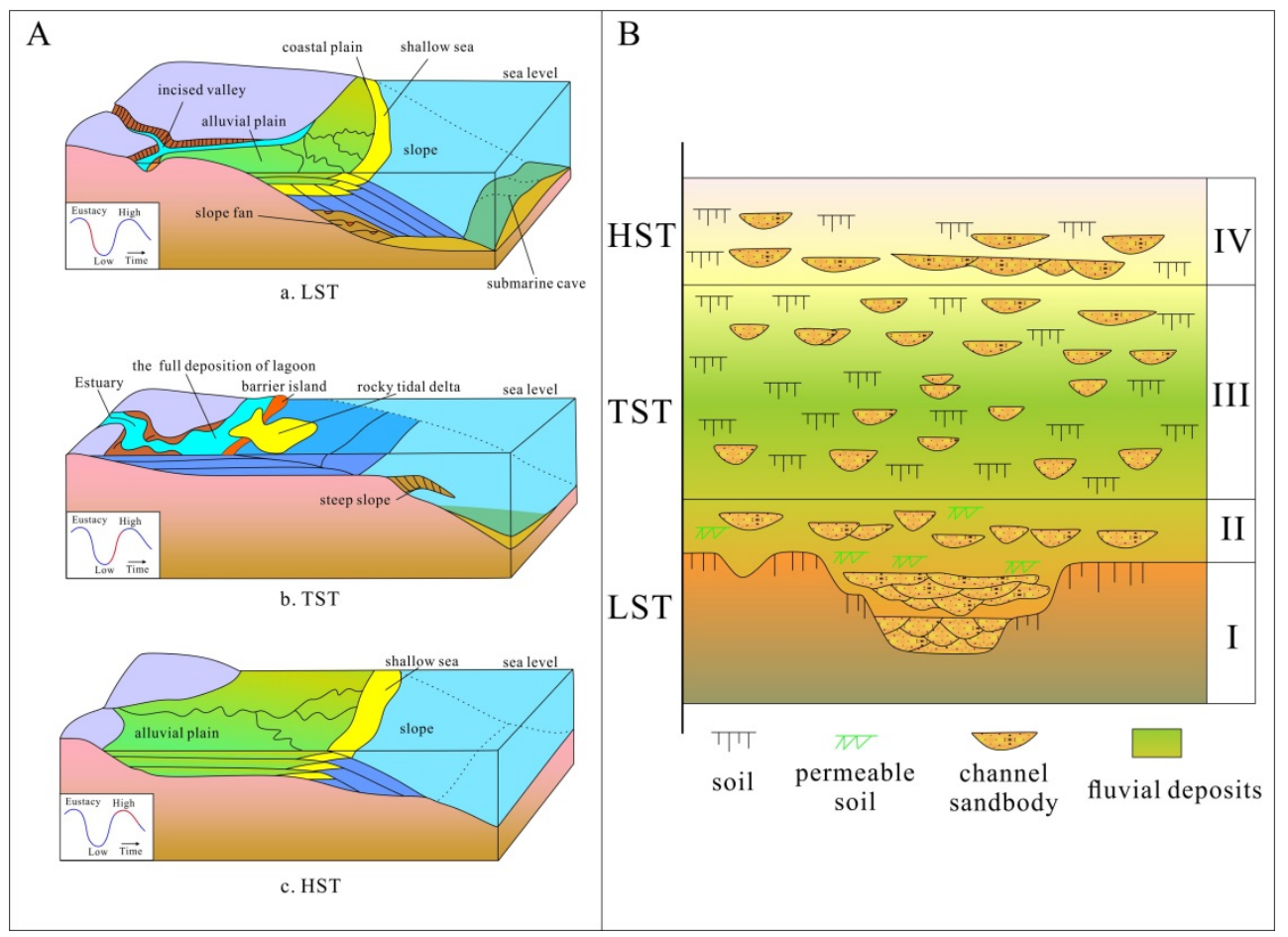

Figure 3. Sequence stratigraphic model in fluvial deposits, A. Characteristics of systems tract in different stages; B. Characteristics of fluvial sequence in different stages of the systems tract

\section{Discussion and Conclusion}

In view of the fact that the model proposed now for the river is not applicable, there are some questions to discuss.

(1) Whether the application of sequence stratigraphy to the analysis and determination of the river facies, but follow the previous system area can meet the actual situation of the river system.

(2) There is no doubt between the river type and the river sequence grid, which can not be denied. But how to better establish the link between each other, so that the river sequence can guide the river type of division, and the river type can reflect the corresponding sequence, to achieve a complete standard.

(3) Whether it is possible to consider the reconstruction of a river sequence system, not the traditional estuary basin or lake entrance basin, but to proceed with the whole of the river system itself, from the source area to the catchment basin.

(4) From the application of the process of sedimentology to the river sequence and river type of research, what we need to do with what works.

Viewing the issues discussed in this article, here are some ideas. The river formation process needs to be distributed from the mountainous area to the sedimentary basin, and the formation of the river can be divided into the low river water scouring stage, the river sedimentation stage, the flood water overflowing stage and the retreatment river reconstruction stage. This is from the history of the evolution of the river to analyze the deposition sequence.

Combined with the study of sediment theory and propose a sequence framework for the inland rivers, new fluvial systems tracts are presented here, including four parts: low fluvial system tract (LFST), advancing fluvial system tract (AFST), flooding fluvial system tract (FFST), receding fluvial system tract (RFST), which separately correspond to the low water systems tract(LST), the transgressive systems tract(TST), the highstand systems tract (HST), and the water back systems tract(BST) in the traditional sequence stratigraphy. The analysis of ideas are in different angles, it will be combined with the river system, and analyze the type of river.

(1) The low fluvial system tract (LFST) is the initial stage of river formation, and the terrain slope is the main factor of river formation. On the original datum, the river carries out the entrainment and the undercut erosion, the water flow is unstable, the occasional flood time carries on the large particle material handling and the river movement, but the overall river hydrodynamic is weak, the water is slim, mainly impacts river bed. So it corresponds to the braided river.

(2) The advancing fluvial system tract (AFST) is the river trunk development period, at this stage, the factors affecting the river system are also much numerous, including structural settlement, climate change, slope, geomorphological 
factors, special geological events, etc. In the process, because the water flow is relatively stable, sediment particles mainly flow in the bottom load and suspension load. So this corresponds to the meandering river.

(3) The flooding fluvial system tract (FFST), which belongs to the sedimentary system formed by the event deposition process. For example, in the late development of the river system of the flood time, originally limited river overflows the embankment, forming the large river flood deposition, and in this long-term role, the river continues to deepen the valley, flooding develops increasingly, and gradually a stable river system is formed, which is exactly the anabranching river.

(4) The receding fluvial system tract (RFST), also divided into event deposition process formed by the deposition system. After the flood event, or the occurrence of a drought event, the river water was reduced and river receded, and the exposed surface of the river bed was composed of the structural features, which could occur in various river types.

Although this idea is proposed for the sequence stratigraphic framework of terrestrial fluvial, it is not still perfect. Therefore, a lot of work is essential to be carried out for further study.

\section{References}

Archer, S. T. (2017). Current management system for a stimulation output stage of an implantable neurostimulation system: Google Patents.

Bonneau, L., Toucanne, S., Bayon, G., Jorry, S. J., Emmanuel, L., \& Jacinto, R. S. (2017). Glacial erosion dynamics in a small mountainous watershed (Southern French Alps): A source-to-sink approach. Earth and Planetary Science Letters, 458, 366-379. https://doi.org/10.1016/j.epsl.2016.11.004

Catuneanu, O. (2006). Principles of sequence stratigraphy: Elsevier.

Chen, L., Lin, Z., Yin, T., Sun, Q., \& Wang, F. (2017). Meandering Process and Migration Architecture: Based on the Nowitna River. Earth Science Research, 6(2), 76-90. https://doi.org/10.5539/esr.v6n2p76

Crombez, V., Rohais, S., Baudin, F., \& Euzen, T. (2016). Facies, well-log patterns, geometries and sequence stratigraphy of a wave-dominated margin: insight from the Montney Formation (Alberta, British Columbia, Canada). Bulletin of Canadian Petroleum Geology, 64(4), 516-537. https://doi.org/10.2113/gscpgbull.64.4.516

Debnath, J., Pan, N. D., Ahmed, I., \& Bhowmik, M. (2017). Channel migration and its impact on land use/land cover using RS and GIS: A study on Khowai River of Tripura, North-East India. The Egyptian Journal of Remote Sensing and Space Science. https://doi.org/10.1016/j.ejrs.2017.01.009

Fryirs, K. A. (2017). River sensitivity: a lost foundation concept in fluvial geomorphology. Earth Surface Processes and Landforms, 42(1), 55-70. https://doi.org/10.1002/esp.3940

Galloway, W. E. (1989). Genetic stratigraphic sequences in basin analysis I: architecture and genesis of flooding-surface bounded depositional units. Aapg Bulletin, 73(2), 125-142.

Gurnell, A., Angold, P., \& Gregory, K. (1994). Classification of river corridors: issues to be addressed in developing an operational methodology. Aquatic conservation: marine and freshwater ecosystems, 4(3), 219-231. https://doi.org/10.1002/aqc.3270040304

Hawie, N., Deschamps, R., Granjeon, D., Nader, F. H., Gorini, C., Müller, C., ... Baudin, F. (2017). Multi - scale constraints of sediment source to sink systems in frontier basins: a forward stratigraphic modelling case study of the Levant region. Basin Research, 29(S1), 418-445. https://doi.org/10.1111/bre.12156

Hu, G., Ni, C., Wang, J., \& Zhao, W. (2011). Review and Problems of Fluvial Sequence Stratigraphy. Geological Science and Technology Information, 36(2), 55-60. http://dx.doi.org/10.3969/j.issn.1000-7849.2011.06.007

Huang, W., Wu, H., Li, J., \& Liu, H. (2016). Study on the Sedimentary System and Favorable Facies of Nantun Formation in the middle Zone of Hailaer-Tamtsag Basin. Acta Sedimentologica Sinica, 36(1), 120-128.

Johnson, J., \& Klapper, G. (1992). North American Midcontinent Devonian TR cycles. Oklahoma Geological Survey Bulletin, 145, 127-135.

Kasvi, E., Laamanen, L., Lotsari, E., \& Alho, P. (2017). Flow Patterns and Morphological Changes in a Sandy Meander Bend during a Flood-Spatially and Temporally Intensive ADCP Measurement Approach. Water, 9(2), 106. https://doi.org/10.3390/w9020106

Leli, I. T., Stevaux, J. C., \& Assine, M. L. (2017). Genesis and sedimentary record of blind channel and islands of the anabranching river: An evolution model. Geomorphology. https://doi.org/10.1016/j.geomorph.2017.05.001

Leopold, L. B., \& Wolman, M. G. (1957). River channel patterns: braided, meandering, and straight: US Government Printing Office. 
Leopold, L. B., \& Wolman, M. G. (1960). River meanders. Geological Society of America Bulletin, 71(6), 769-793. https://doi.org/10.1130/0016-7606(1960)71[769:RM]2.0.CO;2

Lin, Z. (2017). Channel Planform Migration Architecture of Meandering Rivers. Journal of Geology \& Geophysics, 3(3). https://doi.org/10.4172/2381-8719-C1-009

Lin, Z., Chen, L., Shan, J., \& Sun, Q. (2017). Channel Planform Migration Architecture of Meandering Rivers. Asian Journal of Science and Technology, 8(6), 4902-4911.

Lin, Z., Chen, L., Shan, J., Sun, Q., \& Wang, Y. (2017). Migration structures of meandering channels. International Journal of Information Research and Review, 6(4), 4213-4221.

Lin, Z., Shan, J., \& Chen, L. (2017a). Geomorphology Processes of Channel Planform Migration on Meandering Rivers. Acta Geographica Sinica (English Edition), 91, 134-135. https://doi.org/10.1111/1755-6724.13223

Lin, Z., Shan, J., \& Chen, L. (2017b). Meticulous Depiction and Genetic Mechanism of Unconformity Belt Structure. Earth Science Research, 6(2), 19. https://doi.org/10.5539/esr.v6n2p19

Mason, C. C., Fildani, A., Gerber, T., Blum, M. D., Clark, J. D., \& Dykstra, M. (2017). Climatic and anthropogenic influences on sediment mixing in the Mississippi source-to-sink system using detrital zircons: Late Pleistocene to recent. Earth and Planetary Science Letters, 466, 70-79. https://doi.org/10.1016/j.epsl.2017.03.001

Miall, A. D. (2014). Fluvial depositional systems (Vol. 14): Springer. https://doi.org/10.1007/978-3-319-00666-6

Miall, A. D. (2016). Facies Models Stratigraphy: A Modern Synthesis (pp. 161-214): Springer. https://doi.org/10.1007/978-3-319-24304-7_4

Montgomery, D. R., \& Buffington, J. M. (1997). Channel-reach morphology in mountain drainage basins. Geological Society of America Bulletin, 109(5), 596-611. https://doi.org/10.1130/0016-7606(1997)109\%3C0596:CRMIMD\%3E2.3.CO;2

Morón, S., Edmonds, D., \& Amos, K. (2017). The role of floodplain width and alluvial bar growth as a precursor for the formation of anabranching rivers. Geomorphology, 278, 78-90. https://doi.org/10.1016/j.geomorph.2016.10.026

Posamentier, H., Jervey, M., \& Vail, P. (1988). Eustatic controls on clastic deposition I-conceptual framework. Society of Economic Paleontologists and Mineralogists Special Publication 42, 109-124. https://doi.org/10.2110/pec.88.01.0109

Posamentier, H., \& Vail, P. (1988). Eustatic controls on clastic deposition II-sequence and systems tract models. Society of Economic Paleontologists and Mineralogists Special Publication 42, 125-154. https://doi.org/10.2110/pec.88.01.0125

Qian, N. (1985). On the classification and causes of formation of different channel patterns. Acta Geographica Sinica, $40(1), 1-10$.

Rosgen, D. L. (1994). A classification of natural rivers. Catena, 22(3), 169-199. https://doi.org/10.1016/0341-8162(94)90001-9

Sanz-Perez, E., \& Menendez-Pidal, I. (2016). Utility of Geomorphology, Archeology and History in Understanding the Fluvial Dynamics of the Rivers Duero and Tera in Numancia (Soria, Spain). Tecnologia Y Ciencias Del Agua, 7(4), 5-23.

Shan, J., Lin, Z., Chen, L., Liu, B., Fang, W., Zhang, L., \& Xie, L. (2017). A Study of Architecture of Thin Interlayer within Meandering River Monosandbody of Thick-Bedded Oil Layers. Journal of Geography and Geology, 9(3), 16-29. https://doi.org/10.5539/jgg.v9n3p16

Shan, J. f., Wang, F., Sun, H., Sun, J., \& Meng, Q. (2010). Depositional Tectonic Sequences Evolvement of Sedimentary System by Syngenesis Fracture Integrated Mode: An Example From Tabel Depression in Monglia. Geological Review, 56(3), 426-439.

Shanley, K. W., \& McCabe, P. J. (1994). Perspectives on the sequence stratigraphy of continental strata. Aapg Bulletin, 78(4), 544-568.

Sloss, L. (1963). Sequences in the cratonic interior of North America. Geological Society of America Bulletin, 74(2), 93-114. https://doi.org/10.1130/0016-7606(1963)74[93:SITCIO]2.0.CO;2

Stout, J., Rutherfurd, I., Grove, J., \& Kemp, J. (2016). Death of an anabranch: Reconstruction of a Holocene avulsion. Paper presented at the AGU Fall Meeting Abstracts.

Tan, C., Yu, X., Li, S., Li, S., Chen, B., Shan, X., \& Wang, Z. (2014). Discussion on the Model of Braided River Transform to Meandering River:As an example of Toutunhe Formation in Southern Junggar Basin. Acta 
Sedimentologica Sinica, 32(3), 450-458. http://dx.doi.org/10.14027/j.cnki.cjxb.2014.03.009

Tang, W., Wang, Y., Zhao, Z., Zhong, M., Zhao, Y., Tian, J., \& Zou, M. (2016). A Review of Fluvial Pattern Transformation. Geological Review, 62(1), 138-152. http://dx.doi.org/10.16509/j.georeview.2016.01.012

Vail, P. R. (1987). Seismic stratigraphy interpretation using sequence stratigraphy: Part 1: Seismic stratigraphy interpretation procedure.

Vail, P. R., Mitchum Jr, R., \& Thompson III, S. (1977). Seismic stratigraphy and global changes of sea level: Part 3. Relative changes of sea level from Coastal Onlap: section 2. Application of seismic reflection Configuration to Stratigrapic Interpretation.

Van Wagoner, J. C. (1995). Sequence stratigraphy and marine to nonmarine facies architecture of foreland basin strata, Book Cliffs, Utah, USA.

Wright, V. P., \& Marriott, S. B. (1993). The sequence stratigraphy of fluvial depositional systems: the role of floodplain sediment storage. Sedimentary Geology, 86(3-4), 203-210. https://doi.org/10.1016/0037-0738(93)90022-W

Wu, C., Lin, M., Liu, X., \& Qian, S. (2014). Research status and prospect of river pattern classification. Yangtze River, 45(1), 6-11. http://dx.doi.org/10.3969/j.issn.1001-4179.2014.01.003

Wu, X., Hou, J., Wang, D., Cui, Z., \& Shuqing., L. (2014). New Calculation Method for Interlayer Dip and Its Application in Beach-bar Sand Mud Interlayer Depiction. Science \&Technology Review, 12, 48-53.

Xiao, C., Liu, L., \& Chen, Z. (2006). Current Situation of Sequence Stratigraphy and Discussion on Related Theoretic $\begin{array}{lllllll}\text { Problems. Journal of Petroleum and } & \text { Natural }\end{array}$ http://dx.doi.org/10.3969/j.issn.1000-9752.2006.06.001

Yang, G. (2009). Review on advance, status and research frontier of sequence stratigraphy. Petroleum Geology and Engineering, 23(2), 1-4. http://dx.doi.org/10.3969/j.issn.1673-8217.2009.02.001

Zhang, C., Zhang, S., Li, S., Dan, W., \& Hou, L. (2004). Advances in Chinese Fluvial Sedimentology from 1983 to 2003. Acta Sedimentologica Sinica, 22(2), 183-192. http://dx.doi.org/10.14027/j.cnki.cjxb.2004.02.001

Zhang, Z. (1996). Sequence stratigraphy and fluvial type. Geological Review, 42, 188-193.

\section{Copyrights}

Copyright for this article is retained by the author(s), with first publication rights granted to the journal.

This is an open-access article distributed under the terms and conditions of the Creative Commons Attribution license which permits unrestricted use, distribution, and reproduction in any medium, provided the original work is properly cited. 